\title{
Impact of Mivan Formwork over Conventional Formwork
}

\author{
Aaqib Majid Khan ${ }^{1}$, Chitranjan Kumar ${ }^{2}$ \\ ${ }^{1}$ Research Scholar, Department of Civil Engineering, Alfalah University, Faridabad, Haryana, India \\ ${ }^{2}$ Asst Professor, Department of Civil Engineering, Alfalah University, Faridabad, Haryana, India
}

\begin{abstract}
This paper describes in brief the the need of mivan formwork in the Indian construction industry. Construction is one of the significant sectors of Indian economy and is an integral part of the development. With the globalization of Indian economy and introduction of multinationals in India for the construction and nations pride program of golden quadrilateral, it has become foremost to have speedy construction and timely completion of projects. Now days, low waste modern formwork systems for superstructure construction are commonly adopted. Formwork system affects on the cost, time, and quality of project delivery. But still these formwork systems are not much used in India and most of the contractors do not like to shift to the latest technology as they have the doubt of facing losses in the project and they are very much familiar with the existing formwork type, the conventional type. At the same time they believe that these formwork systems are bit expensive. This study is based on the survey conducted on a construction site namely Jaypee Krescent Homes at sec 134 Noida UP. This paper describes the comparative analysis of conventional formwork and tailor made (MIVAN) formwork on the basis of cost, quality time and strength parameters.
\end{abstract}

\section{Introduction}

The traditional mode of construction for individual houses comprising load bearing walls with an appropriate roof above or reinforced concrete (RC) framed structure construction with infill masonry walls would be totally inadequate for mass housing construction industry in view of the rapid rate of construction. Further, such constructions are prone to poor quality control even in case of contractors with substantial resources and experience.

"For undertaking mass housing works, it is necessary to have innovative technologies which are capable of fast rate construction and are able to deliver good qualityand durable structure in cost effective manner".

Several systems are adopted at different places in the world; eventually the systems which are reasonably economical and easy for operation with skilled labor are useful in India. Certain systems are in vogue and more and more contractors are trying to bring in new technologies. These are essentially based on the basis of mode of construction, namely, pre-cast construction or in-situ construction.

\section{Formwork}

When concrete is placed, it is in plastic state. It requires to be supported by temporary supports and castings of desired shape till it becomes sufficiently strong to support its own weight. This temporary casing is known as the formwork or forms or shuttering. The term moulds is sometimes used to indicate formwork of relatively small units such as lintels, cornices etc.

\subsection{Definition of formwork}

"Forms or moulds or shutters are the receptacles in which concrete is placed, so thatit will have desired shape or outline when hardened. Once concrete develops the adequatestrength to support its own weight they can be taken out”.
"Formwork is the term given to either temporary or permanent moulds into whichconcrete or similar materials are poured".

Requirements of a good formwork

The essential requirements of formwork or shuttering are: -

a) It should be strong enough to take the dead and live loads during construction.

b) The joints in the formwork should be rigid so that the bulging, twisting, or sagging due to dead and live load is as small as possible. Excessive deformation may disfigure the surface of concrete.

c) The construction lines in the formwork should be true and the surface plane so that the cost finishing the surface of concrete on removing the shuttering is the least.

d) The formwork should be easily removable without damage to itself so that it could be used repeatedly.

\subsection{Types of Formwork}

The material most commonly being used to date is timber. However, due to the depleting forest reserves and increasing cost of timber the use of alternate materials such as plywood and steel has become prominent. More recently, materials such as plastics and fiberglass are also being used for prefabricating formwork. The type of material to be used depends on the nature of construction as well as availability and cost of material. The constraints on the project such as overall cost, time of completion also play a major role in the use of a Particular material for formwork.

Timber Formwork

Steel Formwork

Plastics Formwork

\subsection{Aluminium Formwork (MIVAN)}

Forms made from aluminum are in many respects similar to those made of steel. However, because of their lower density, aluminum forms are lighter than steel forms, and this is their primary advantage when compared to steel. As the strength of aluminum in handling, tension and 


\section{International Journal of Science and Research (IJSR) \\ ISSN (Online): 2319-7064 \\ Index Copernicus Value (2015): 78.96 | Impact Factor (2015): 6.391}

compression is less than the strength of steel, it is necessary to use large sections. The formwork turns out to be economical if large numbers of reuses are made in construction. The major disadvantage of aluminum forms is that no changes can be made once the formwork is fabricated.

\subsection{MIVAN: - A Versatile Formwork}

The system of aluminum forms (MIVAN) has been used widely in the construction of residential units and mass housing projects. It is fast, simple, adaptable and cost effective. It produces total quality work which requires minimum maintenance and when durability is the prime consideration. This system is most suitable for Indian condition as a tailor-made aluminum formwork for cast-insitu fully concrete structure.

\subsection{Background}

Mivan is basically an aluminium formwork system developed by one of the construction company from Europe. In 1990, the Mivan Company Ltd from Malaysia started the manufacturing of such formwork systems. Nowadays more than 30,000 sq $\mathrm{m}$ of formwork used in the world are under their operation. In Mumbai, India there are number of buildings constructed with the help of the above system which has been proved to be very economical and satisfactory for Indian Construction Environment.

The technology has been used extensively in other countries such as Europe, Gulf Countries, Asia and all other parts of the world. MIVAN technology is suitable for constructing large number of houses within short time using room size forms to construct walls and slabs in one continuous pour on concrete. Early removal of forms can be achieved by hot air curing / curing compounds. This facilitates fast construction, say two flats per day. All the activities are planned in assembly line manner and hence result into more accurate, well - controlled and high quality production at optimum cost and in shortest possible time.

In this system of formwork construction, cast - in - situ concrete wall and floor slabs cast monolithic provides the structural system in one continuous pour. Large room sized forms for walls and floors slabs are erected at site. These forms are made strong and sturdy, fabricated with accuracy and easy to handle. They afford large number of repetitions (around 250). The concrete is produced in RMC batching plants under strict quality control and convey it to site with transit mixers.

The frames for windows and door as well as ducts for services are placed in the form before concreting. Staircase flights, facade panels, chajjas and jails etc. and other prefabricated items are also integrated into the structure. This proves to be a major advantage as compared to other modern construction techniques.

The method of construction adopted is no difference except for that the sub - structure is constructed using conventional techniques. The super-structure is constructed using MIVAN techniques. The integrated use the technology results in a durable structure.

\subsection{Modular Formwork}

The formwork system is precisely-engineered system fabricated in aluminium. Using this system, all the elements of a building namely, load bearing walls, columns, beams, floor slabs, stairs, balconies etc can be constructed with cast in place concrete. The resulting structure has a good quality surface finish and accurate dimensional tolerances. Further, the construction speed is high and the work can be done in a cost effective manner.

The modular nature of the formwork system allows easy fixing and removal of formwork and the construction can proceed speedily with very little deviation in dimensional tolerances. Further, the system is quite flexible and can be easily adapted for any variations in the layout.

The availability of concrete from ready mix concrete facility has augured well for the use of this work system. However, the proliferation of RMC facilities in the cities in India and the willingness to use mechanized means of transport and placing of concrete, the use of aluminium formwork system has received a boost. The quality of the resulting concrete is found to be superior.

Structurally speaking, the adoption of the closed box system using monolithic concrete construction has been found to be the most efficient alternatives. The stresses in both the concrete and steel are observed to be much lower even when horizontal forces due to wind or earthquake are taken into consideration.

The formwork system can be used for construction for all types of concrete systems, that is, for a framed structure involving column beam -slab elements or for box-type structure involving slab-walls combination.

\section{Construction Activities with Mivan Formwork}

The construction activities are divided as pre - concrete activities, during concreting and post - concrete activities. They are as follows:

\subsection{Pre - Concrete Activities}

a) Receipt of Equipment on Site - The equipments is received in the site as ordered.

b) Level Surveys - Level checking are made to maintain horizontal level check.

c) Setting Out - The setting out of the formwork is done.

d) Control / Correction of Deviation - Deviation or any correction are carried out.

e) Erect Formwork - The formwork is erected on site.

f) Erect Deck Formwork - Deck is erected for labours to work.

g) Setting Kickers - kickers are provided over the beam.

After the above activities have been completed it is necessary to check the following.

1) All formwork should be cleaned and coated with approved realize agent.

2) Ensure wall formwork is erected to the setting out lines. 


\section{International Journal of Science and Research (IJSR) \\ ISSN (Online): 2319-7064 \\ Index Copernicus Value (2015): 78.96 | Impact Factor (2015): 6.391}

3) Check all openings are of correct dimensions, not twist.

4) Check all horizontal formwork (deck soffit, and beam soffit etc.) in level.

5) Ensure deck and beam props are vertical and there is vertical movement in the prop lengths.

6) Check wall ties, pins and wedges are all in position and secure.

7) Any surplus material or items to be cleared from the area to be cast.

8) Ensure working platform brackets are securely fastened to the concrete.

\subsection{On Concrete Activities}

At least two operatives should be on standby during concreting for checking pins, wedges and wall ties as the pour is in progress. Pins, wedges or wall ties missing could lead to a movement of the formwork and possibility of the formwork being damaged. This - affected area will then required remedial work after striking of the formwork. Things to look for during concreting:

1) Dislodging of pins / wedges due to vibration.

2) Beam / deck props adjacent to drop areas slipping due to vibration.

3) Ensure all bracing at special areas slipping due to vibration.

4) Overspill of concrete at window opening etc.

\subsection{Post - Concrete Activities}

1) Strike Wall Form- It is required to strike down the wall form.

2) Strike Deck Form- The deck form is then removed.

3) Clean, Transport and stack formwork

4) Strike Kicker Formwork - The kicker are removed.

5) Strike wall - Mounted on a Working Platform the wall are fitted on next floor.

6) Erect Wall - Mount Working Platform and the wall is erected.

Normally all formwork can be struck after 12 hours. The post - concreting activities includes:

\subsection{Cleaning}

All components should be cleaned with scrapers and wire brushes as soon as they are struck. Wire brush is to be used on side rails only. The longer cleaning is delayed, the more difficult the task will be. It is usually best to clean panels in the area where they are struck.

\subsection{Transporting:}

There are basic three methods recommended when transporting to the next floor:

1) The heaviest and the longest, which is a full height wall panel, can be carried up the nearest stairway.

2) Passes through void areas.

3) Rose through slots specially formed in the floor slab for this purpose. Once they have served their purpose they are closed by casting in concrete filter

\subsection{Striking}

Once cleaned and transported to the next point of erection, panels should be stacked at right place and in right order. Proper stacking is a clean sign of a wall - managed operation greatly aids the next sequence of erection as well as prevents clutters and impend other activities

\subsection{Objective of Study}

1) To compare the cost of building by using conventional formwork technique \& by using MIVAN formwork technique.

2) To compare the Duration of building by using conventional formwork technique \& by using MIVAN formwork technique.

3) To carry out which formwork is best for construction of building.

4) To understand the concept of MIVAN formwork

All above mention points will have been studied on alive case study.

\section{Comparison of Mivan formwork system with Conventional Construction}

The below shows the relative comparison between the Mivan form work system and the conventional system. The comparison is made on the factors such as speed of construction, quality of construction, aesthetics, external finishes and maintenance.

\section{Speed of construction}

The speed of construction is much slower due to step by step completion of different stages of the activities such as erection of formwork, concreting and deshuttering and thereafter plastering and other finishing activities. In this system the wall and the floors are casted simultaneously in one continuous operation and also the finishing work can be started immediately, so the speed of the construction is much faster.

\section{Quality}

Due to conventional method of construction normal quality is obtained. Superior quality is obtained due to in-situ casting of whole structure and transverse walls done in continuous operation

\section{Aesthetics}

In the case of conventional construction the partition walls are made up of bricks due to which the column and the beam show unsightly projections in room interiors. In case of Mivan system the partition wall and the ceiling elements are casted together due to which the interiors have neat and clean lines without unsightly projections in various corners. The wall and the ceilings also have a smooth even surface.

\section{External finishes}

All the external walls are made up of bricks, so it requires manual cement plastering which needs to be repainted frequently.

All the external walls are made up of concrete and do not require manual cement plastering and also have smooth finishing, so this will need no frequent repainting.

\section{Volume 6 Issue 7, July 2017 www.ijsr.net}




\section{International Journal of Science and Research (IJSR) \\ ISSN (Online): 2319-7064 \\ Index Copernicus Value (2015): 78.96 | Impact Factor (2015): 6.391}

Maintenance

The maintenance cost is too high as it requires frequent repairs of plasters of wall and ceilings, painting of outer and inner walls due to leakages. The maintenance cost is negligible as the walls and ceiling are made up of high quality concrete which do not require frequent repairs.

\section{Cost Comparison}

Comparison on the basis of the on site survey conducted at Jaypee Krescent Homes Noida UP.

Details of the building:

This project is a part of the massive housing project at sec.135 Noida UP.The name of the project whole project is Jaypee Wish Town, and the survey is carried out on the Jaypee Crescent Homes tower no.30.Here are the details of the building.

1) Grade of concrete :M35

2) Slump :180mm-200mm

3) Wall thickness :External:200mm;Internal:100mm

4) Steel :Partition wall:10mm; Structural:12mm; ShearWall:16mm

5) Slab thickness: Hall=175mm; Bedroom:150mm; Kitchen: $125 \mathrm{~mm}$

6) Finishing: Internal: Paint over gypsum; External: Texture paint

7) No.of floors

:25 Floors

8) Area

:3BHK 184sq.m

\begin{tabular}{|c|c|c|c|c|}
\hline $\begin{array}{c}\text { S. } \\
\text { No }\end{array}$ & Parameter & $\begin{array}{c}\text { Cost by } \\
\text { Conventional } \\
\text { technology }\end{array}$ & $\begin{array}{c}\text { Cost by } \\
\text { Mivan } \\
\text { Technology }\end{array}$ & Cost Saving \\
\hline \multirow{2}{*}{1} & $\begin{array}{c}\text { Shuttering after } \\
\text { repitations }\end{array}$ & $\begin{array}{c}\text { Wooden materials= } \\
\text { Rs 88.50/sq.m } \\
\text { MS Material= } \\
\text { Rs.100/sq/m }\end{array}$ & $\begin{array}{c}\text { Rs.83.8/ } \\
\text { sq.m }\end{array}$ & Rs.104.63/sq/m \\
\hline 2 & Concreting & Rs.1400/sq.m & 1505 & Rs.- $105 / \mathrm{sq} / \mathrm{m}$ \\
\hline 3 & Reinforcement & Rs.1480/sq.m & 2115 & Rs.-635.2/sq/m \\
\hline 4 & Brickwork & Rs.484/sq.m & 0 & Rs.480/sq/m \\
\hline 5 & Plaster & Rs.700/sq.m & 0 & Rs.700/sq/m \\
\hline \multicolumn{4}{|c|}{ Total cost saving } & Rs.548.43 \\
\hline
\end{tabular}

Comparison based on strength:

Admixture used:Master Glenium ACE 30 JP

Specifications:

- Appearance

:Brownish liquid

- Specific Gravity

$: 1.00-1.02 \mathrm{gm} / \mathrm{cm} 3$

- PH Value

Concrete Mix Design:

- Grade designation

- Type of cement

- Reduced water content for admixture

- Mix design

Conventional concrete

Concrete using Admixture

$\cdot 1: 1.2: 3.2$

Slump Test Result

\begin{tabular}{|c|c|c|}
\hline Sr.No & Description & Slump \\
\hline 1 & Conventional concrete & $100 \mathrm{~mm}$ from top \\
\hline 2 & Concrete using Admixture & $200 \mathrm{~mm}$ from top \\
\hline
\end{tabular}

Compressive testing result

\begin{tabular}{|c|c|c|c|c|c|}
\hline \multirow{2}{*}{ S.No } & Day & \multicolumn{2}{|c|}{ Load (KN) } & \multicolumn{2}{c|}{ Strength N/mm ${ }^{2}$} \\
\cline { 3 - 6 } & Conventional & $\begin{array}{c}\text { Admixtured } \\
\text { concrete }\end{array}$ & Conventional & $\begin{array}{c}\text { Admixtured } \\
\text { concrete }\end{array}$ \\
\hline 1 & 7 & 414 & 453 & 18.4 & 20.17 \\
\hline 2 & 14 & 577 & 610 & 25.67 & 27.12 \\
\hline 3 & 28 & 798 & 910 & 35.48 & 40.12 \\
\hline
\end{tabular}

By using admixture the workability of concrete is increased by 120 whereas the strength of concrete is increased by $12 \%$.

\section{Comparison based on time}

\section{Work cycle}

MIVAN is a system for scheduling \& controlling the work of other connected construction trades such as steel reinforcement, concrete placements \& electrical inserts. The work at site hence follows a particular sequence. The work cycle begins with the deshuttering of the panels. It takes about $12-15 \mathrm{hrs}$. It is followed by positioning of the brackets \&platforms on the level. It takes about 10-15hrs simultaneously.

The deshuttered panels are lifted \& fixed on the floor. The activity requires 7-10hrs Kicker and External shutters are fixed in $7 \mathrm{hrs}$. The wall shutters are erected in 6-8 hrs. One of the major activity reinforcement requires 10-12 hrs. The fixing of the electrical conduits takes about $10 \mathrm{hrs}$ and finally pouring of concrete takes place in these.

This is a well synchronized work cycle for a period of 7 days. A period of 10-12 hrs is left after concreting for the concrete to gain strength before the beginning of the next cycle. This work schedule has been planned for 1010-1080 $\mathrm{sq} \mathrm{m}$ of formwork with $72-25 \mathrm{cu} \mathrm{m}$ of concreting \& approximate reinforcement.

The formwork assembling at the site is a quick \& easy process. On leaving the MIVAN factory all panels are clearly labeled to ensure that they are easily identifiable on site and can be smoothly fitted together using formwork modulation drawings. All formwork begins from corners and proceeds from there.

The system usually follows a four day cycle: -

Day 1: -The first activity consists of erection of vertica reinforcement bars and one side of the vertical formwork for the entire floor or a part of one floor.

Day 2: -The second activity involves erection of the second side of the vertical formwork and formwork for the floor

Day 3: - Fixing reinforcement bars for floor slabs and casting of walls and slabs.

Day 4: -Removal of vertical form work panels after 24hours, leaving the props in place for 7 days and floor slab formwork in place for 2.5 days 


\section{International Journal of Science and Research (IJSR) \\ ISSN (Online): 2319-7064}

Index Copernicus Value (2015): 78.96 | Impact Factor (2015): 6.391

\section{References}

[1] Ramesh Kannan, Helen Santhi, "Constructability Assessment of Climbing Formwork Systems Using Building Information Modeling", International Conference on Design and Manufacturing, IConDM 2013.

[2] Desai D.B. "Emerging Trends in Formwork - Cost Analysis \& Effectiveness of Mivan Formwork over the Conventional Formwork" IOSR Journal of Mechanical and Civil Engineering (IOSR-JMCE) ISSN: 2278-1684, PP: 27-30.

[3] Kaustubh Dasgupta“Seismic Design of slender Reinforced Concrete Structural Wall"

[4] Marisa Pecce, Francesca Ceroni, Fabio A. Bibbo,Alessandra De Angelis, "Behavior of RC 5. Building with large lightly reinforced walls along the perimeter", Engineering Structures 73(2014) 39-53, April 2014.

[5] M.S.Medhekar, S.K.Jain, "Seismic behavior, design \& detailing of RC shear Building Formwork". Building construction By B.C.Punmia (2008 edition).

[6] IOSR Journal of Mechanical and Civil Engineering (IOSR-JMCE),Miss. Patil Dhanashri Prof. Desai D B

[7] International Journal of Innovative Research in Science, Engineering and Technology Vol. 3, Issue 6, June 2014, Patel Abhiyan S, Neeraj Sharma D, Bhavin K Kashiyani. 